\title{
Grammatical and communicative competences as one: a study on symbouletic modality
}

\author{
Competências gramatical e comunicativa integradas: um estudo da modalidade simboulética \\ Claudia Strey \\ Escola Superior de Propaganda e Marketing - Porto Alegre, RS, Brasil
}

Monica Monawar ${ }^{1}$

Universidade Federal de Santa Catarina - Florianópolis, SC, Brasil

\begin{abstract}
The present paper aims to raise awareness of the importance of an integrated teaching of semantics and pragmatics, especially the linguistic-communicative competence in the additional language classroom. In order to support it, we have discussed symbouletic modality, a natural language phenomenon that takes place precisely at the interface of form and use. At first we discuss Kratzer's $(1981,1991,2012)$ framework for natural language modality and Yanovich's (2013a, 2013b) proposal for the symbouletic modal flavor. After that, we discuss pragmatic cognitive tools for language process analysis in the form of conceptual and procedural meanings, based on Sperber and Wilson's (1995) relevance theory. Lastly, by this illustration, we reinforce our original argument, hoping to bridge further the gap sometimes found between linguistic research and additional language pedagogy.
\end{abstract}

Keywords: Semantics; Symbouletic modality; Pragmatics; Procedural meaning

Resumo: O presente artigo busca a conscientizar sobre a importância de uma abordagem integrada de semântica e pragmática no ensino, especialmente a respeito da competência linguístico-comunicativa na sala de aula de língua adicional. Para dar suporte a isto, discutimos a modalidade simboulética, um fenômeno da linguagem natural que ocorre precisamente na interface entre forma e uso. Primeiramente, discutimos o arcabouço teórico de Kratzer (1981, 1991, 2012) para a modalidade em linguagem natural, além da proposta de Yanovich (2013a, 2013b) para a modalidade simbulética. Depois, discutimos as ferramentas da pragmática cognitiva para analisar o processamento da linguagem, especialmente em relação ao significado procedural e conceitual, baseados na Teoria da Relevância, de Sperber e Wilson (1995). Finalmente, via esta ilustração, reforçamos nosso argumento original, esperando construir uma ponte que diminua a distância que por vezes é encontrada entre a pesquisa em linguística e a pedagogia de língua adicional.

Palavras-chave: Semântica; Modalidade simboulética; Pragmática; Significado procedural

\section{Introduction}

The present paper stems from theoretical and applied experiences when teaching additional languages. Subscribing to a methodological approach that considers as more important grammar, or communication, imposes a clear-cut distinction between them, a void that seems unsurpassable. Seeking to build bridges between research discourse and pedagogical discourse, this paper aims

\footnotetext{
1 I would like to thank CAPES and their National Post-Doctorate Program (PNPD) for their financial support.
}

to discuss the phenomenon of symbouletic modality as inherently an interface topic between semantics and pragmatics, in order to better illustrate what often seems unavoidable in the additional language classroom: we should not, in fact, we cannot separate grammar from communication, form from use.

The tools here chosen to address symbouletic modality arise from the interface of formal semantics and cognitive pragmatics. Moreover, we address this modal flavor cross-linguistically (English and Brazilian Portuguese, contrastively) in order to arrive at the ultimate objective here: to raise awareness of the 
importance of an integrated teaching of semantics and pragmatics, especially the fostering of a unified linguisticcommunicative competence in the additional language classroom $^{2}$. Phenomena like symbouletic modality seem to pose a challenge if one seeks to discuss linguistic competence isolated from communicative competence, or even to teach them separately - interaction and communication play a central role that permeates different levels, including the syntactic-semantic structure.

Firstly, we approach the semantics of symbouletic modality under Kratzer's $(1981,1991,2012)$ framework and Yanovich's (2013a, 2013b) proposal of a new modal flavor - symbouletic modality. Secondly, we offer a pragmatic take on procedural meaning in order to better account for the dynamics of this phenomenon. Finally, a few considerations are drawn considering the importance of approaching these competences, grammatical (linguistic) and communicative (pragmatic) in a unified way, integrating, for instance, semantics and pragmatics in additional language teaching practices.

\section{The semantics of symbouletic modality}

The study of modality within formal semantics, having as a starting point the formalist search for what takes place in the mind of the speaker, for instance, "what do I know/what happens in my mind when I think and talk about possibilities and necessities?" generally does not concern itself primarily with matters related to language teaching - it is a matter of scope. Nevertheless, the investigation yields a lot of potential for interfaces like the one proposed in this paper. Here, initially, form takes methodological precedence in the analysis of this natural language phenomenon within this approach, and its articulation with pragmatics is not only ultimately desirable, but quite necessary in order to better grasp the particular type of modality we aim to discuss here, as well to fulfill the objectives we have set. As the carver and his method shape the stone to his liking within its possibilities, the type of stone might sometimes have intricacies that require particular tools and techniques in order to fully approach it.

Let us first discuss the type of stone we have here, modality. Epistemic modality, for example, is not inherently performative - it is more descriptive, static, referring to speaker's knowledge/evidence of $p$. The type of modality, or modal flavor, that we discuss here

\footnotetext{
2 The topic and its peculiarities, as well as the intricacies of the interfaces proposed cannot, due to space restrictions, be exhausted here. In this paper, we elaborate on fundamental, theoretical aspects of the description and analysis of this modal flavor in these two languages and its application in the debate about competences, so that future work can focus on experimental approaches to test and enhance our proposal.
}

is in that aspect unlike epistemic modality - symbouletic modality, the modal flavor of advice and/or suggestion, is in essence performative; it does not take place outside interaction or without the presence of an addressee, it requires communication. Here, this modal flavor of advice is accounted for within Kratzer's $(1981,1991,2012)$ framework for the semantic analysis of modality in natural language and Yanovich's (2013a, 2013b) expansion on priority modals to include this new, symbouletic flavor. In the subsections that follow both approaches will be addressed respectively.

\section{Kratzer's (1981, 1991, 2012) framework}

The analysis of modality in natural language owes Angelika Kratzer quite a lot. She expanded the apparatus of possible worlds from modal logic because, mainly, its two operators - could not account for the different nuances of graded possibility present in natural language. Her ordering semantics, then, provides the tools to analyze possibility in terms of a graded scale based on contextual information. The final reading of a modal auxiliary is dependent on two parameters - the double relativity of a modal - a modal base and an ordering source. The first restricts the scope of the proposition, it can be paraphrased as a "in the view of..." sentence. Consider the example below:

(1) John might be out of battery.

(2) In view of what I know about John (he always has his cell phone with him, he never turns it off, etc.), John might be out of battery.

In (2), the 'in view of' clause paraphrases the modal scope over the proposition, that is, it concerns my knowledge of John and his usual behavior, not my knowledge of other things and people, much less the law or my desires - other examples of modal readings. Kratzer (2012) affirms that paraphrasing is a much less common practice when compared to just leaving it up to context to fill in the gaps. So, if I say (1) to someone, this person will run the paraphrase in (2) on their own by accessing contextual information. This parameter is necessary because of modal underspecification, that is, Kratzer's framework does not consider each different reading a modal verb may have as a brand-new lexical entry - 'must' connected to knowledge or deduction is not a different entry from 'must' connected to the law, for example - allowing thus for one and the same lexical entry 'must' to be underspecified enough so that it can encompass many possible readings, be them epistemic, deontic, etc.. Therefore, the modal base is one of the parameters that come forth to narrow down the scope of 
the modal. Even so, the matter of modal force had still been left unattended, and that propelled the need for a second parameter: the ordering source. Having had the modal base done a selection of all the worlds in which there are propositions where I have knowledge of John and his cell phone manners, for example, a second parameter, also given by context, orders the worlds previously selected by the modal base. It establishes an ordering according to an ideal, and the worlds are placed in this order in a way that, the higher the number of propositions that correspond to the ordering source are true in the world, the higher it ranks, the more optimal it is in relation to that ideal. So, in (1), 'might' does not carry out the same modal force 'must' would, as in (3):

\section{(3) John must be out of battery.}

The amount of worlds in which propositions are true within the modal scope proposed and with the ideal established by the ordering source, that is, John is a person who would not turn off his phone for any other reason, is bigger in (3) than in (1), consequently yielding graded possibility. Kratzer (1991) claimed that, in natural language, specific modal verbs could themselves impose restrictions on their use, i.e., not combining with a particular type of modal base or ordering source. Mapping out a descriptive relation of modal verbs according to how they combine with modal bases and ordering sources would, according to the author, give us the basics of the modal system of that language. Kratzer has offered one for German, reproduced below:

Table 1. The modal system of German according to Kratzer (1991, p. 650)

\begin{tabular}{llll}
\hline muss & Modal Force & \multicolumn{1}{c}{ Modal Base } & \multicolumn{1}{c}{ Ordering Source } \\
kann & necessity & no restrictions & no restrictions \\
darf & possibility & no restrictions & no restrictions \\
soll ${ }_{1}$ & necessity & circumstantial & $\begin{array}{l}\text { deontic, teleological } \\
\text { ('in view of certain aims') }\end{array}$ \\
soll ${ }_{2}$ & necessity & empty & $\begin{array}{l}\text { houletic ('in view of } \\
\text { certain wishes') }\end{array}$ \\
wird & weak necessity & epistemic & $\begin{array}{l}\text { doxastic ('in view of } \\
\text { certain beliefs') }\end{array}$ \\
dür'te & weak necessity & epistemic & stereotypical \\
\hline
\end{tabular}

Kratzer's model, according to Yanovich (2013a, p. 19) adequately proposes the description and analysis for particular instances of modals, lacking the tools to describe differences that can be grouped in three issues, as he describes them: "[f]actors affecting which conversational backgrounds get used by natural languages; modal meaning change; interpretational restrictions on modals specific to particular linguistic contexts". Here we will address the first and third issues, intertwined in the phenomenon of a particular modal flavor, symbouletic modality.

\section{Symbouletic Modality (YANOVICH, 2013b)}

As aforementioned, modal ambiguity allows for a variety of possible interpretations, some restricted by the modal verb itself - some verbs do not combine with some modal bases or particular ordering sources ${ }^{3}$ - and others provided contextually via modal base and ordering source. Epistemic modality concerns speaker's knowledge/evidence; deontic modality relates to laws; bouletic, to wishes; teleological, to objectives or goals; and so on. For example, (4) derives deontic interpretation, with its modal restriction potentially paraphrased as "in view of the laws of Brazil":

(4) People who are 16 or older may vote.

It is, therefore, allowed, possible, for people of that age (16) or older to vote, according to Brazilian law. Taking that into consideration, imagine that John is Brazilian and he has just had his sixteenth birthday. It is election year and John's mom says to him (5):

(5) You should vote.

John, according to the law, still has the possibility of not voting - it is only obligatory for people who are 18 years old or older. After his eighteenth birthday his mother would, perhaps, speak differently, and utter (6):

(6) You must vote.

In (6), 'must' does not leave the same room for worlds where John does not vote as (5) does, the ordering is different. Here, closest to the ideal are the worlds in which John does indeed vote, respecting the law of his country ${ }^{4}$. So far, so good, we seem here to have a performative use of deontic 'should' and 'must', which can also be descriptive, static, when used to state what the law prescribes, for example. Could, then, the following examples be categorized as deontic?

(7) You should go to that concert.

(8) You should see a doctor.

(9) You should take time off.

\footnotetext{
3 For example, 'must' cannot be felicitously used when sensorial evidence is available to the speaker, one does not say 'It must be raining' if one sees rain outside.

4 Considering the scope and objective of this paper, we will not detail the analysis nor formalize it. We refer to Scarduelli and Pires de Oliveira (2008); Pessotto (2015) for further reading on this subject.
} 
It seems that the examples above cannot have their modal restrictions paraphrased as "in view of the law...", so they cannot be deontic readings. They do not concern speaker's wishes, so they are not bouletic; they do not necessarily seem to address the goals of the addresse, especially in (7) and (8), so they are not teleological. Yanovich (2013b) coins another type of modal flavor, namely restricted to suggestions and advice, symbouletic. Unlike other modal flavors that are either static (describing the state of affairs) or have instantiations in which they are performative (like in examples (5) and (6) above), symbouletic modality is inherently performative. The author identifies a Russian modal verb that is strictly symbouletic, 'stoit', and argues that one of the reasons why this type of modality has not been looked into thus far is because in English (and other languages that are vastly addressed in linguistic research, like German, for example) modal underdetermination allows for 'should' to be symbouletic, deontic, epistemic, etc - the restriction falls upon the contextual information drawn by the modal base and the ordering source. This modal ambiguity, according to the author, may have hindered the unveiling and discussion of symbouletic modality. Cross-linguistic evidence, like the Russian 'stoit' and what we will illustrate here with the imperfective marking in Brazilian Portuguese modal verbs, provides further reflection on the description and analysis of this type of modality and, moreover, given its performative nature, how pragmatics can be articulated with this framework. As Yanovich (2013a, p. 208) points out, due to the fact that symbouletic modality concerns specifically contexts of interaction between speaker and hearer, pragmatic analyses find here "fertile ground for generating and recovering implicatures", also claiming that this new flavor of modality instills fuel to the "emerging novel collective research program into the "modality-pragmatics interface" (YANOVICH, 2013b, p. 1).

Considering the inherent performative force of symbouletic modality, it cannot, unlike static readings, be challenged as a lie. Taking (8), for example, "You should see a doctor" cannot be challenged as a lie, as if that is not what the speaker is suggesting. In this way, the author states that symbouletic modality patterns itself with imperatives.

Firstly, Yanovich (2013b, p. 11) supplies the parameters of symbouletic modality following Kratzer's framework:

[a] metaphysical modal base and stereotypical ordering source: $y$ has control over $p$ at index $i$ iff among stereotypically optimal worlds among the metaphysically accessible worlds at index $i$, there are $p$-worlds and $\neg p$-worlds, and furthermore, there are actions available to $y$ that bring about $p$, and similarly to $\neg p$.
Furthermore, the author provides the core properties of symbouletic modality: Decision, Advice Consistency and Performative Force, we will address them promptly.

There is a semantic presupposition to symbouletic modality, that "at the evaluation time, y has control over achieving $p$ " (YANOVICH, 2013b, p. 11). We cannot address (7), (8), or (9) to an addressee who, for any reason, cannot perform those actions. Within that presupposition, the property of Decision is encoded: " $y$ has the control over whether a $p$-future will actualize or not, and it is not yet given that $p$ will actualize" (YANOVICH, 2013b, p. 8). The property of Advice Consistency, quite selfexplanatory, concerns the notion that, after having advised $p$, the speaker cannot advise $\neg p$.

Performative force, as mentioned before, is an essential property of symbouletic modality. Even though this modal flavor parallels itself with imperatives due to its performative nature, the strength of the performative force in symbouletic modality is not the same as in imperatives: on a scale that has on one end an assertion describing what state of affairs would be optimal for the addressee and on the other end the the imperative. In between, a conditional directive represented by symbouletic modality, stronger than an assertion yet weaker than an imperative, thus between "factual assertions and commands" (YANOVICH, 2013b, p. 13). By using this modal flavor we are not describing what would be best for the addressee nor commanding them to do it, but urging, yet leaving it up to them to act upon $p$ or not.

\section{Symbouletic Modality in Brazilian Portuguese}

Russian has a strictly symbouletic modal, 'stoit'; English has enough modal ambiguity that 'should' and 'ought to' can have symbouletic readings ${ }^{5}$. Brazilian Portuguese (henceforth BP), in turn, has a very lean modal system, consisting of three modal auxiliaries: 'ter que' ('have to'), 'dever' ('must', 'ought to', 'might') and 'poder' ('can', 'may'). Considering their lexical ambiguity, Kratzerian restrictions of modal base and ordering source come into play in order to restrict the possible readings. Example (8) could be translated as (10) below, with its English version in (11):

(10) Você deve ir ao médico.

(11) You must/ought to see a doctor.

However, the only reading available is not strictly symbouletic: 'dever' here could also be deontic if, for

\footnotetext{
We do not attempt to offer a modal system for symbouletic modality in English, but only to follow Yanovich's (2013b) examples in that language.
} 
example, the context of utterance would involve an admission exam before being employed by a company. Consequently, 'dever' is not strictly symbouletic, it relies widely on the restrictions imposed by the modal base and the ordering source. Given a different context, in which the mother says (10) to her child because they look ill, it then is restricted into a symbouletic reading.

Unlike English, BP modals have aspectual and temporal overt marking. It seems to be the case that the marking of imperfective aspect in BP 'dever', as in 'devia', structurally restricts the reading ${ }^{6}$, not leaving room for non-symbouletic use. (10) would then become (12), with its version in English in (13):

(12) Você devia ir ao médico.

(13) You should see a doctor.

Considering von Fintel and Iatridou (2008), this would be the case of a necessity modal combining with counterfactual marking, yielding weaker necessity. This counterfactual marking in the BP imperfective could, perhaps, structurally signal a difference in reading, no longer deontic, but symbouletic. Not plain directive, but conditional directive. Counterfactual morphology that would, furthermore, be coherent with Yanovich's metaphysical modal base for symbouletics.

\section{The role of pragmatics}

The distinction between what is meaning and what falls between the scope of semantics and pragmatics is one of the most discussed questions in linguistics. However, the distinction between 'sentence meaning' and 'speaker meaning' is not always clear, and some examples of natural language may raise important questions about how it works. If we consider (14):

Mary is a princess.

from a semantic perspective, we would be able to describe different aspects related to metaphor for example; while from a pragmatic perspective, the meaning of the utterance expressed and its speaker's meaning would vary depending on the context (she resembles an actual princess, she is very polite, she is beautiful) $)^{7}$. The example (14) shows that it is problematic to understand word meaning as purely semantic, free from pragmatics.

\footnotetext{
6 We will not delve deeper into this matter here, for it is under development elsewhere (Monawar, in prep.).

7 Considering the scope of this paper, we will not discuss metaphors, since it is an extensive topic. For more, see Carston (2002, 2010); Gibbs and Tendhal (2006); Wilson and Carston (2006).
}

The same seems to be the case for symbouletic modality, as aforementioned. A pure semantic analysis is not able to fully explain the performative nature of the modal in this reading. Its behavior has to be explained within a pragmatic theory of communication, one that in the Gricean spirit explains more than what is said. Once we grasp how pragmatics enriches the propositional content and alters the salience of certain assumptions, we will have a better understanding of natural language meaning. In the next subsection, we will discuss how relevance theory may help explain how semantics and pragmatics are bound together.

\section{Relevance and communication}

Sperber and Wilson's (1995) Relevance Theory, henceforth TR, is a theory that aims to establish a cognitive and a communicative principle in order to explain inferential communication ${ }^{8}$ :

(15) First, or Cognitive Principle of Relevance: human cognition tends to be geared to the maximisation of relevance

(16) Second, or Communicative Principle of Relevance: every ostensive stimulus conveys a presumption of its own optimal relevance.

Where presumption of optimal relevance is:

$$
\begin{aligned}
& \text { Presumption of optimal relevance: (a) The ostensive } \\
& \text { stimulus is relevant enough for it to be worth the } \\
& \text { addressee's effort to process it; (b) The ostensive } \\
& \text { stimulus is the most relevant one compatible with the } \\
& \text { communicator's abilities and preferences. }
\end{aligned}
$$

The communicative principle (16) states that relevance can be defined as a property of inputs - cognitive effects gained versus processing effort expended. Other things being equal, the more cognitive effects and less processing effort expended, the greater the relevance of the input to the individual. By the cognitive principle (15), the theory implies that by overtly displaying an intention to produce ostensive stimuli, the speaker creates a presumption that the stimulus is relevant enough to be worth processing. This second point is quite important in the analysis of symbouletic modality, especially in terms of additional language teaching. In BP, for example, in order to derive the modal force, BP speakers use a marked prosody (MONAWAR and STREY, 2015) - which means prosody is a relevant stimuli to be worth processing. In an

\footnotetext{
8 The formulation of the two principles and the presumption of optimal relevance is the one presented in the postface of the second edition of Relevance (1995).
} 
intercultural environment, this input may not be picked up by speakers who are not proficient enough, and this may cause misunderstandings.

Turning to the second principle - the communicative one, Wilson and Sperber (2004, p. 259) build a relevanceguided comprehension heuristic, which is shown below:

Relevance-theoretic comprehension procedure

a. Follow a path of least effort in computing cognitive effects: Test interpretive hypotheses (disambiguations, reference resolutions, implicatures, etc.) in order of accessibility.

b. Stop when your expectations of relevance are satisfied.

For RT, the inferential process happens on both explicit and implicit levels. For this to be possible, it bets on the existence of an intermediate level between what is said and what is implied: the explicature - a logical form of the proposition developed. Sperber and Wilson (1995) explain that an explicature combines what is linguistically encoded with what is contextually inferred, and it is at this level that different pragmatic operations occur like disambiguation, and reference assignment. The theory foresees the recovery of a basic explicature the enrichment of the logical form - and the construction of a higher-level explicature, which requires more pragmatic development such as determining the propositional attitude or embedding the basic proposition into a speech-act ${ }^{9}$.

From the relevance theoretic background, one point is relevant to the discussion of symbouletic modality: the distinction between conceptual and procedural meaning.

\section{Conceptual and procedural meaning}

An important distinction in relevance theory is the one between conceptual and procedural meaning, which was introduced by Blakemore $(1987,2002)$. According to Carston (2002) the discussion about the nature of word meaning has gone with the view that most open-class words encode concepts, but the idea that words might not encode full-fledged concepts, but something like constraints, instructions for building concepts, or rules for use, has been gaining popularity recently (WILSON and SPERBER, 1993; BLAKEMORE, 1987, 2002; WILSON, 2014; WHARTON, 2009, 2015).

\footnotetext{
9 Despite the importance of explicature for relevance theory, there are important discussions (LEVINSON, 2000; RECANATI, 2004; BACH, 2006) about the existence of such theoretical construct, which rekindles the debate about the semantics-pragmatics interface.
}

Words like 'dog' encode content and contribute to the truth-conditions of a sentence; whilst words like 'therefore' encode procedures and carry a non-truth conditional meaning, guiding the inferential comprehension process. In relevance theory, procedural constrain the search of relevance, interacting with contextual assumptions and cognitive effects, as we can see in (19):

(19) It's sunny today, so I am wearing sunscreen.

In(19), 'so' does not affect the content of the utterance, rather it indicates the relationship between propositions: it guides the hearer to make one interpretation more salient than other: the speaker is going to wear sunscreen because it is sunny, and not despite of it.

The procedural-conceptual distinction has been applied to different phenomena. However, if early stages of research showed if the distinction was a matter of truth-conditional and non-truth-conditional meaning, it was later clear that the parallel works in different ways (WILSON, 2014). Sperber and Wilson frame their discussion about the distinction in a diagram, which can be seen in Figure 1.

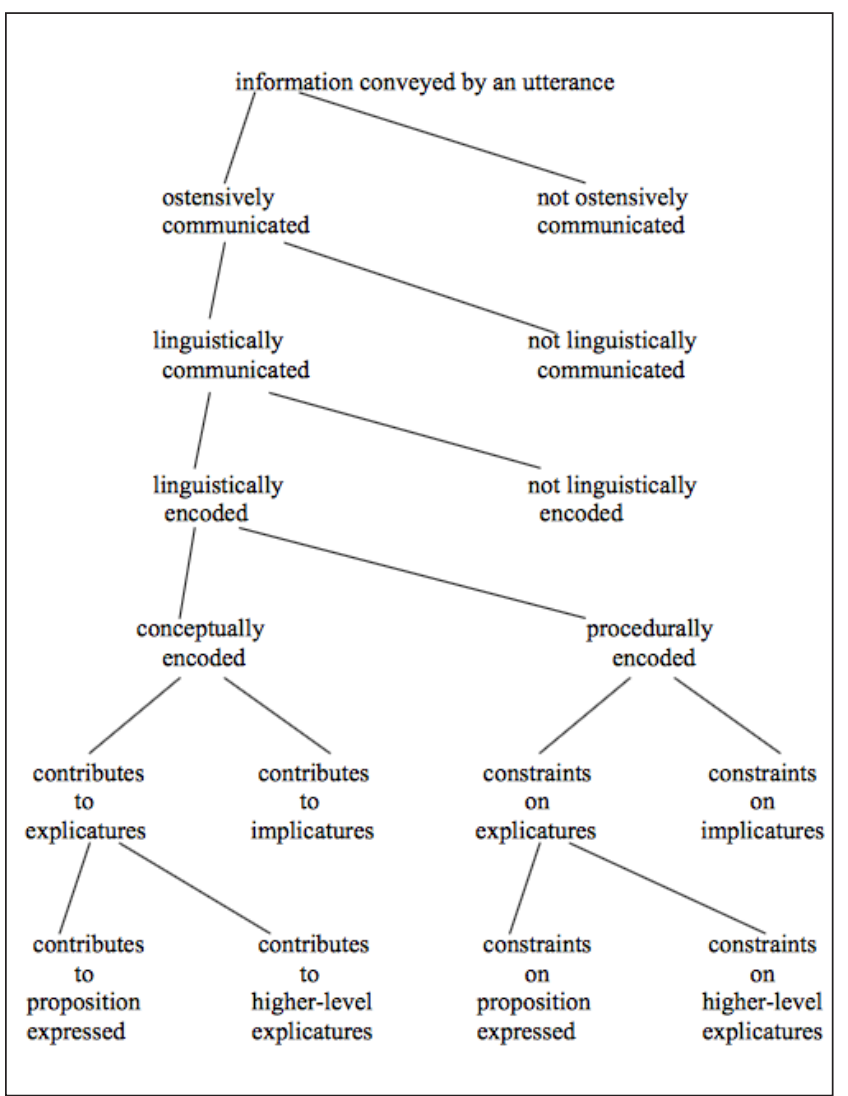

Figure 1. Conceptual and procedural meaning. Source: Wilson and Sperber (1993). 
In Figure 1, we are going to focus on two points that may help explain how context helps select the modal reading, which is procedural constraints on the proposition expressed and higher-level explicatures.

Procedural constraints on the proposition expressed: some words and some inputs are procedural and impose constraints on explicature, guiding the search for what is part of the proposition. One example is the pronouns, for example 'he' is not referring to any specific person, but narrow the search to assign the referent for some man, not a woman.

Procedural constraints on higher-level explicature: the constraint is on the higher level explicature, which is built by embedding the basic explicature under a speechact or propositional-attitude description. It is the case of interjections, which narrow the search for speaker's intention.

Prosody seems to be one example that may encode a procedural constraint on the proposition expressed. That seems to be the case for symbouletic modal readings in Brazilian Portuguese, as discussed by Monawar and Strey (2015), where native speakers seem to indicate via intonation the force of a determinate final modal reading.

We claim here that symbouletic modality also marks the higher-level explicature, especially considering aspectual and temporal overt marking. The marking of imperfective aspect constrains the reading of the modality: it indicates that the reading of the modal is symbouletic, and that the speech act is of advising. Considering that this modal flavor builds itself on interaction, its analysis seems to require a nonlinear, multi-directional approach, an interface that can provide tools in order to describe and explain its inner workings.

Assuming the relevance-theoretic comprehension procedure, the marking of aspectuality increases the hearer's processing effort, but it encourages the hearer to look for extra effects. Imagine the following situation: your friend wants to spend New Year's Eve at the beach, but she is not an experienced driver. She asks for your opinion, and you tell her:

(20) Você devia ir de ônibus para a praia.

(21) You should take the bus to the beach.

The hearer would have to interpret the utterance by decoding it and making inferences about the speaker's meaning - and the imperfective is one clue to guide the interpretation. It narrows the reading of the modal verb, constraining the higher-level explicature:

(22) $x$ is advising me to take the bus to the beach.

However, a change in the context may alter the interpretation, and a proficient hearer would then be able to comprehend the imperfect not as marking of symbouletic reading, but as politeness. Consider the following context: your eighteen-year-old son has just gotten his driver's license and is going to spend New Year's Eve at the beach with his friends. He asks to borrow your car. You tell him:

(23) Você devia ir de ônibus para a praia.

(24) You should take the bus to the beach.

In a relevance-theoretic comprehension procedure, the interpretive hypothesis that 'devia' has a symbouletic reading is not the most accessible, because context does not license this reading due to the assumptions that are yielded, for example:

(i) The son is not an experienced driver.

(ii) There is a lot of traffic during New Year's break.

(iii) If there is an accident, the son may not be insured.

(iv) Due to the hierarchy evident in a parent-child relationship, the parent has authority over the matter, as well as being the owner of the vehicle in question.

Unlike what has been evidentiated by (20), (21) and (22), where the social relationship between friends does not involve hierarchical authority of one over the other, as well as where the addressee's personal benefit takes priority - the core of the practice of giving advice -, the second situation does not concern the son's benefit, but leaves virtually no room for him to make the decision to continue his course of action. Therefore, it ultimately could be reported in the same way as a command, which conveys the higher-level explicature (25) below, and no longer as seen in (22):

(25) My mother/father told me to go to the beach by bus.

These examples illustrate native speaker processing of semantic and pragmatic contexts, which would, in theory, be performed equally by a proficient speaker but the same may not be possible to say about a learner of BP as an additional language. Thus, we reinforce the need for an integrated approach to grammatical and communicative competences in additional language teaching.

\section{Final remarks}

In this paper, we have set out to address the distinction between the long-standing concepts of linguistic and communicative competences in additional languages, challenging their divide. In order to do so, we have called upon a natural language phenomena that requires the merge of both competences into one, linguisticcommunicative, in order for successful interaction to 
be attained. Thus, we have explored the semantics of symbouletic (advice/suggestion) modality, providing a brief overview of Kratzer's $(1981,1991,2012)$ framework for the analysis of modality in natural language, and then using Yanovich's (2013a, 2013b) development of the symbouletic modal flavor, as inherently performative, as a diving board into pragmatics.

Then, we laid our attention to how communication is processed, assuming a cognitive-communicative approach of pragmatics. We provided a brief overview of Sperber and Wilson's (1986/1995) relevance theory, in which the distinctions between procedural and conceptual meaning were discussed. Scrutinized inside a theory that aims to cognitively explain how we understand each other, the study of symbouletic modality is an example of how underdeterminacy requires both semantic and pragmatic processes to produce meaning.

Finally, the aim of this paper was to argue that the distinction, as well as the division of labor, between semantics and pragmatics is quite blurred, especially if we consider elements that are intrinsic to language in interaction. We have shown that symbouletic modality is a phenomenon subscribed to an interface between areas, and it serves as an illustration that grammar studies and communication cannot be separated.

\section{References}

BLAKEMORE, Diane. Semantic Constraints on Relevance. Oxford: Blackwell, 1987.

BLAKEMORE, Diane. Relevance and linguistic meaning: The semantics and pragmatics of discourse markers. Cambridge: Cambridge University Press, 2002.

BACH, Kent. Impliciture vs. explicature: What's the difference? Paper delivered at Workshop on Explicit Communication. Granada, 2006.

CARSTON, Robyn. Metaphor, ad hoc concepts and word meaning - more questions than answers. UCL working papers in linguistics, v. 14, p. 83-105, 2002.

CARSTON, Robyn. Lexical pragmatics, ad hoc concepts and metaphor: from a relevance theory perspective. Italian Journal of Linguistics, v. 22, n. 1, p. 153-180, 2010.

GIBBS, Raymond; TENDHAL, Markus. Cognitive Effort and Effects in Metaphor Comprehension: Relevance Theory and Psycholinguistics. Mind \& Language, v. 21, n. 3, p. 379-403, 2006.

KRATZER, Angelika. The Notional Category of Modality. In: EIKMEYER, H. J.; RIESER, H. (Org.). Words, Worlds and Contexts. Berlin and New York: de Gruyter. 1981. p. 38-74.

KRATZER, Angelika. Modality. In: STECHOW, Arnim Von; WUNDERLICH, Dieter. Semantik/Semantics: An International Handbook of Contemporary Research. Berlin: de Gruyter Mouton, 1991. p. 639-650
KRATZER, Angelika. Modals and Conditionals: New and Revised Perspectives. New York: Oxford University Press, 2012. Vol. 36

LEVINSON, Stephen C. Presumptive Meanings: the theory of generalized conversational implicature. Cambridge: MIT Press, 2000

MONAWAR, Monica; STREY, Claudia. The interference of prosody in interpretation of symbouletic modality: a study of Brazilian Portuguese. In: BUJA, Elena; MADA, Stanca. Structure, use, and meaning in intercultural settings. Braşov: Editora Universitatii Transilvania, 2015. p. 169-180.

MONAWAR, Monica. The imperfective as symbouletic marking in Brazilian Portuguese modals. (In prep.).

OLIVEIRA, Roberta Pires de; SCARDUELLI, Jaqueline Alves. Explicando as diferenças semânticas entre TER QUE e DEVER: uma proposta em semântica de mundos possíveis. Alfa, São Paulo, v. 52, n. 1, p. 215-234, 2008.

PESSOTTO, Ana Lúcia. Força e evidência: uma análise teórico-experimental da semântica de 'pode', 'deve' e 'tem que'. 2015. Tese (Doutorado em Linguística) - Programa de Pós-graduação em Linguística, Universidade Federal de Santa Catarina, Florianópolis, 2015.

RECANATI, François. Literal Meaning. Cambridge: Cambridge University Press, 2004.

SPERBER, Dan; WILSON, Deirdre. Relevance: Communication and Cognition. 2. ed. Cambridge: Blackwell Publishing, 1995 (1986).

FINTEL, Kai Von; IATRIDOU, Sabine. How to Say Ought in Foreign: The Composition of Weak Necessity Modals. In: GUERÓN, Jacqueline; LECARME, Jacqueline (Ed.). Time and Modality. New York: Springer, 2008. p. 115-141.

WHARTON, Tim. Pragmatics and Non-Verbal Communication. Cambridge: Cambridge University Press, 2009.

WHARTON, Tim. That bloody so-and-so has retired: expressives revisited. Lingua, v. 175-176, 2015.

WILSON, Deirdre; SPERBER, Dan. Relevance Theory. Linguistics, Psychology/Psycholinguistics, v. 26, 2014.

WILSON, Deirdre; SPERBER, Dan. Linguistic form and relevance. Lingua, v. 90, n. 1, p. 1-25, 1993.

WILSON, Deirdre; CARSTON, Robyn. A unitary approach to lexical pragmatics: relevance, inference and ad hoc concepts. In: BURTON-ROBERTS, Noel (Ed.). Pragmatics (Basingstoke: Palgrave Mauage), v. 21, n. 3, p. 379-403, 2006.

YANOVICH, Igor. Four pieces for modality, context and usage. $\mathrm{PhD}$ dissertation - Massachusetts Institute of Technology, Cambridge, 2013.

YANOVICH, Igor. On advice modality. Los Angeles: UCLA, 2013b.

Recebido: 22 de abril de 2017

Aprovado: 24 de junho de 2017

Contato:

Claudia Strey <claudiastrey@pucrs.br>

Monica Monawar $<$ monicamonawar@pucrs.br $>$ 